\title{
To Move Between and Often Within
}

\author{
Theophilus Kwek
}

ABSTRACT: In February 2017, the Office of the United Nations High Commissioner for Human Rights (OHCHR) released a damning report of human rights abuses perpetrated against the Rohingya. The report was based on interviews with Rohingya fleeing from Myanmar since 9 October 2016, with research continuing up to January 2017. Many recounted personal experiences of violence and physical, life-threatening harm. The report received some attention among humanitarian agencies (many of which have been banned from accessing Rakhine state) but was largely ignored by the international press. Headlines that week focused on the Trump administration's attempts to defend its travel ban. This poem contains fragments and modifications of the report. It is not an attempt to supplant the voices of those at the heart of the report, but-by stripping down its language - an attempt to make (and mend) our ways of reading (and hearing) their stories.

KEYWORDS: displacement, eyewitness, OHCHR, poetry, Rohingya, violence

All titles (in bold), and some lines in the poem are taken directly from the Flash Report of the OHCHR's Mission to Bangladesh, 'Interviews with Rohingyas Fleeing from Myanmar since 9 October 2016', published on 3 February, 2017 and available at https://www.ohchr.org/Documents/ Countries/MM/FlashReport3Feb2017.pdf.

\section{To move ${ }^{1}$ between, and often within}

1. Go in a specified direction or manner, change position; Alter the space, or shape of; Change one's place of residence or work; (Of a player) change the position of a piece in a board game;

townships, procedures to secure ${ }^{2}$ travel

Depart. 2. (Of a door) Make hard to open, fasten, or lock; Protect against threats, make safe; Succeed in obtaining, especially with difficulty; Fix (something) so that it cannot be moved or lost. 
are onerous and time $e^{3}$-consuming.

3. A moment or definite portion

of time allotted; The appropriate or expected time, in particular of childbirth or death; The indefinite continued progress of existence; A prison sentence;

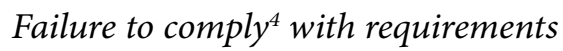

An instance or occasion. 4. To act in accordance with a wish or command;

Meet specified standards; Late $16^{\text {th }}$ Century

from Latin complere, fill up, fulfil

(the original sense was "accomplish,"

can result in arrest ${ }^{5}$ and prosecution.

Hence "oblige" or "obey"). 5. Seize by legal authority; Detain; Stop or check (a process, a disease); A sudden cessation of movement; To attract attention (as in, "the stillness of the place arrested her").

\section{Several victims mentioned}

Death

, the destruction of property and the displacement of 140,000

people due to shooting at close range

due to stabbing by knife

due to beating by the security forces

by five army officers in front of our eyes

of the foetus

due to random firing

and her two sisters killed

[...] Maybe

they held each other tight, that could be why they seemed to be hugging in there, my brother said.

\section{Families may have had members killed,}

Your pen wavers on the stroke, severs

beaten, raped, and / or taken away

"and" from "or." After calamity, a small

to an unknown location, while at the same time

chance, a breath - such sweet distance, in

their homes were burned and looted. For most

this language of yours. You tell me 
interviewees, separation

it is a good and merciful tongue.

from their families is a major concern.

In our own it never rains, but pours.

\section{My Father}

stood up, which is when a grenade came listen: here the things I was killed at the same time as I was shot remember. the armed who was also living with me men were wearing green uniforms, a prayer leader some with plain patterned pants, and some with was slaughtered with a knife a kind of camouflage pattern, like was called out from all of us women and children leaves. They totally burned, together with three others were the same color paid the army up to 1 million kyat for my release as helicopters.

\section{Have crossed the border pictured below}

My country sells its islands whole.

My country lets its cities grow.

My country takes care of your soul.

My country keeps your taxes low.

My country holds its secrets close.

My country builds above the sea.

My country makes your emperor's clothes.

My country lets your country be.

My country has its own to feed.

My country is your country's womb.

My country knows it has no need.

My country says it has no room.
This led

to many

Families

\section{Moving}

from village

to village

and

Ultimately

leaving

the country

for safety.

THEOPHILUS KWEK is a writer and researcher based in Singapore. He has published four volumes of poetry, most recently The First Five Storms, which won the New Poets' Prize in 2016. His poems, translations, and essays have appeared in The Guardian, Times Literary Supplement, Irish Examiner, Mekong Review, and The London Magazine. He presently serves as Co-Editor of Oxford Poetry and The Kindling. 